Sains Malaysiana 50(10)(2021): 2937-2944

http://doi.org/10.17576/jsm-2021-5010-08

\title{
Distribution of Pesticides in Different Commonly Grown Vegetables of Cameron Highlands, Pahang, Malaysia
}

(Penyebaran Racun Makhluk Perosak pada Sayuran Sepunya yang Ditanam Berbeza di Tanah Tinggi Cameron, Pahang, Malaysia)

\author{
Nusrat Munawar, Yang Farina*, Mohammad Yaqoob, Abdul Nabi \& Syed Munawar Shah
}

\section{ABSTRACT}

Gas chromatography-electron capture detector (GC-ECD) is used to extract and analyse pesticides in vegetable samples collected from Cameron Highlands, Pahang, Malaysia. The limit of detection (LOD) for all pesticides was in the range of 0.03 to $4.5 \mathrm{ng} \mathrm{g}^{-1}$. Recoveries in cabbage, lettuce, and celery ranged from $61.8 \%-121 \%, 60-128 \%$ and $60 \%$ $114 \%$, respectively. The relative standard deviation (RSD) ranged $0.2-15 \%$ in cabbage, $0.5-18 \%$ in lettuce and $3-19.8 \%$ in celery. Organochlorine pesticides (OCPS) concentrations increased down the valley with dichlorodiphenyldichloroethylene (DDE) having the highest concentration at $233 \mu \mathrm{g} \mathrm{kg}^{-1}$. Organophosphorus pesticides (OPPS) were found to be dispersed throughout the valley, with the highest concentration of parathion ethyl (133 $\mu \mathrm{g} \mathrm{kg-1})$ whereas the pyrethroid pesticides (PYRs) concentrations were comparatively less. The detection frequency in the wet season was highest $(5<-<100$ $\mu \mathrm{g} \mathrm{kg}^{-1}$ ) for most pesticides. However, in the dry season the pesticides concentrations were higher, at $<5 \mu \mathrm{g} \mathrm{gg}^{-1} . P C \mathrm{~A}$ analysis indicated that farmers were using a mixture of pesticides.

Keywords: Gas chromatography; health risk; pesticides; vegetables

ABSTRAK

Gas kromatografi-pengimbas penangkap elektron (GC-ECD) digunakan untuk mengekstrak dan menganalisis sampel sayur dari Tanah Tinggi Cameron, Pahang, Malaysia. Had pengesanan (LOD) untuk semua pestisid berada dalam lingkungan 0.03 hingga $4.5 \mathrm{ng} \mathrm{g}^{-1}$. Perolehan semula bagi kobis, daun salad dan seleri masing-masing berada dalam lingkungan 61.8\%-121\%, 60\%-128\% dan 60\%-114\%. Sisihan piawai relatif (RSD) adalah 0.2-15\% dalam kobis, 0.5-18\% dalam daun salad dan 3-19.8\% dalam seleri. Kepekatan pestisid organoklorin (OCPS) bertambah apabila turun ke lembah dan diklorodifenildikloroetilena (DDE) mempunyai kepekatan tertinggi pada $233 \mu \mathrm{g} \mathrm{kg}^{-1}$. Pestisid organofosforus (OPPS) tersebar di sekitar lembah dan paration etil mempunyai kepekatan tertinggi (133 $\left.\mu \mathrm{g} \mathrm{kg}^{-1}\right)$ manakala kepekatan pestisid piritroid (PYRs) sangat kurang. Frekuensi pengesanan pada musim tengkujuh adalah tertinggi $(5<-<100 \mu \mathrm{g}$ $\mathrm{kg}^{-1}$ ) untuk semua jenis pestisid. Manakala untuk musim kering, kepekatan pestisid lebh tinggi pada kepekatan $<5$ $\mu \mathrm{g} \mathrm{kg-1}$. Analisis PCA menunjukkan bahawa petani menggunakan campuran pelbagai pestisid.

Kata kunci: Kromatografi gas; racun perosak; risiko kesihatan; sayur-sayuran

\section{INTRODUCTION}

Pesticides are toxic, bio-accumulative, and persistent having an adverse effect on the natural environment and humans (Ligani \& Hussen 2014). The organochlorine pesticides (OCPs) residues show spatial and temporal distribution around the world because dissipation is affected by many factors including agricultural practices, applications, history, and meteorological factors such as temperature, rainfall, and solar radiation (Hao et al. 2008). The dissipation of pesticides varies greatly with the change in vegetable species (Gao et al. 2008). The World Health
Organization (WHO) reports (2003) that vegetables and fruits constitute $30 \%$ of a consumer's diet as they are good sources of vitamins, minerals, antioxidants, and fibre. Pesticide contamination can affect human health, animals, and the environment in many ways (Bhanti \& Taneja 2007; Farina et al. 2018; Park et al. 2016). Studies indicated that certain fruits and vegetables which contain higher pesticide residue and above maximum residue limit (MRL) could pose a health hazard to consumers (Sinha et al. 2012). Therefore, pesticide monitoring is important for the protection of human health. 
This work aims to examine the distribution of pesticides in the agricultural areas of Cameron Highlands, Malaysia situated in Pahang state, with an estimated area of $712 \mathrm{~km}^{2}$ and its location on the main range of Peninsular Malaysia between 4-20' N - 4-37' N and 101 20 '-101 36' E. Its altitude is between $1280-1830 \mathrm{~m}$ above the sea level. The average annual rainfall is 2800 $\mathrm{mm}$ and daily temperatures are between and $14-21^{\circ} \mathrm{C}$. Agriculture is the main occupation of the people of this region. Due to continuous cultivation and use of pesticides in the highlands the rivers had been contaminated by OCPs, OPPs, and PYRs (Abdullah et al. 2015; Ismail \& Haron 2017; Ngan et al. 2005; Tan \& Beh 2015).

\section{MATERIALS AND METHODS}

The pesticide standards were purchased from Dr. Ehrenstorfer, Augsberg, Germany with purity ranging from $94-100 \%$. Stock solutions $\left(1000 \mu \mathrm{g} \mathrm{mL} \mathrm{m}^{-1}\right)$ of pesticides were prepared by dissolving required quantities in $10 \mathrm{~mL}$ acetone and stored in brown glass bottles at $<-16{ }^{\circ} \mathrm{C}$. From these stock solutions working standards were prepared and stored at $4{ }^{\circ} \mathrm{C}$. The working standards were prepared from the stock solution and stored at $4{ }^{\circ} \mathrm{C}$ (Farina et al. 2018).

A chopped vegetable sample of $10 \mathrm{~g}$ samples spiked with $5.0 \mathrm{~mL}$ of spiking solution of $1.0 \mathrm{mg} \mathrm{L}^{-1}$ was taken in a blender, spiked and allowed to stand for $20 \mathrm{~min}$ for interaction and extracted with $65 \mathrm{~mL}$ acetonitrile for 1.0 min at high speed. A combination of $12.0 \mathrm{~g}$ sodium chloride and $12.5 \mathrm{~g}$ anhydrous magnesium sulfate were added to remove moisture. The recovered $30 \mathrm{~mL}$ organic extract was evaporated in a rotary evaporator at $40{ }^{\circ} \mathrm{C}$ to bring its final volume up to 1.0-2.0 $\mathrm{mL}$. The extraction was followed by a cleanup step using a multilayer superclean graphited carbon black (GCB)/primary secondary amine (PSA) SPE cartridge, pre-conditioned with a mixture of $5.0 \mathrm{~mL}$ solution of toluene-acetone $(1: 3 \mathrm{v} / \mathrm{v})$. After loading the acetonitrile extract, the elution was brought about at a flow rate of $5.0 \mathrm{~mL} \mathrm{~min}^{-1}$ by a mixture of $5.0 \mathrm{~mL}$ acetone- toluene. The eluate was evaporated under the nitrogen stream up to $0.5 \mathrm{~mL}$ followed by the addition of PCNB $\left(1.0 \mu \mathrm{g} \mathrm{mL}^{-1}\right)$ solution in acetone as an internal standard and analysis by GC-ECD method.

\section{APPARATUS AND CHROMATOGRAPHIC CONDITIONS}

A Varian chrome pack CP-3800 GC equipped with $63 \mathrm{Ni}$ ECD was used. The carrier gas was high purity nitrogen with a $1.5 \mathrm{~mL} \mathrm{~min}{ }^{-1}$ flow rate. Detector and injector were operated at $300{ }^{\circ} \mathrm{C}$ and $250{ }^{\circ} \mathrm{C}$, respectively; the oven temperature was kept at $90{ }^{\circ} \mathrm{C}$ for 1.0 min and then programmed at $3.5^{\circ} \mathrm{C} \mathrm{min}-1$ to $170{ }^{\circ} \mathrm{C}$ followed by a final ramp to $280{ }^{\circ} \mathrm{C}$ at $5.0^{\circ} \mathrm{C} \mathrm{min}^{-1}$. A $1.0 \mu \mathrm{L}$ of each sample was injected into the GC using split-less mode. The retention time was used to identify the correct peak on the chromatogram (Farina et al. 2017).

\section{RESULTS AND DISCUSSION}

The method was validated and optimized by using cabbage, lettuce, and celery as representative matrices. Linearity was checked with triplicate injections in the concentration range of $0.5-3.0 \mathrm{mg} \mathrm{L}^{-1}$. The sensitivity of the method was evaluated using the limit of detection (LOD) and limit of quantification (LOQ). For recovery and repeatability, triplicate analysis tests were performed to evaluate the accuracy and precision at three fortification levels. The linearity range and correlation coefficients (r) obtained were from 0.990 - 0.995 for all studied pesticides. The LOD and LOQ of the method were considerably lower than the maximum residue limits (MRL) established by the European Union. The LOD for all pesticides ranged from $0.02-4.5 \mu \mathrm{g} \mathrm{g}^{-1}$. Recoveries ranged 61.8 - 121, $60-128$, and $60-14 \%$ in cabbage, lettuce, and celery, respectively, which indicates that the method is accurate.

Vegetable samples were collected from seven different areas of Cameron Highlands at two different seasons (wet and dry). The concentration level for each pesticide at seven different sites are shown in Figures 1 (wet) and 2 (dry). Most of the pesticides were detected in both seasons. In case of OCPs, it seems that the total concentration of pesticides in wet season increases as we move down the valley in Brinchang, Habu, and Ringlet, $(\alpha-\mathrm{HCH}, \beta-\mathrm{HCH}, \gamma-\mathrm{HCH}, \mathrm{DDT}$, DDD, and DDE; 26.6, 70, 41, 33.3, 133 and $100 \mu \mathrm{g} \mathrm{kg}^{-1}$, respectively). Endosulphan's highest concentration was found at Raja village $\left(51 \mu \mathrm{g} \mathrm{kg}^{-1}\right)$. This could be due to higher pest infestation used by farmers and its continuous wash off by rain and slope of the area (Mazlan \& Mumford 2005; Saadati et al. 2012). The topography of the area along with the air circulation also plays an important role in the distribution of pesticides in the study area. During the night, air moves down the valley, while during day time it moves towards the mountains due to the difference in the cooling gradient of the atmosphere. However, since this downward drift is faster than upward, that may not allow the pollutants to be not well distributed in the atmosphere (Sulaiman et al. 2007). 


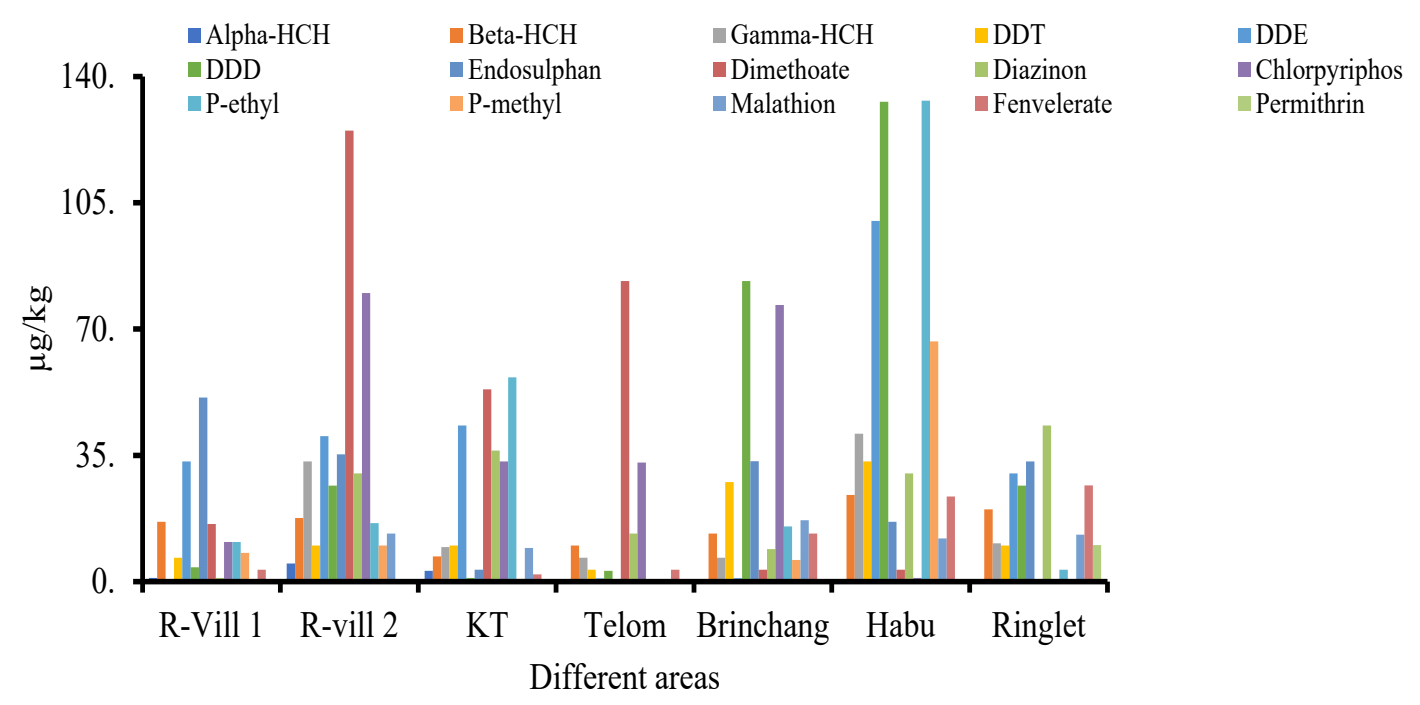

FIGURE 1. Concentration levels of pesticides in the vegetable sample from seven different areas during wet season

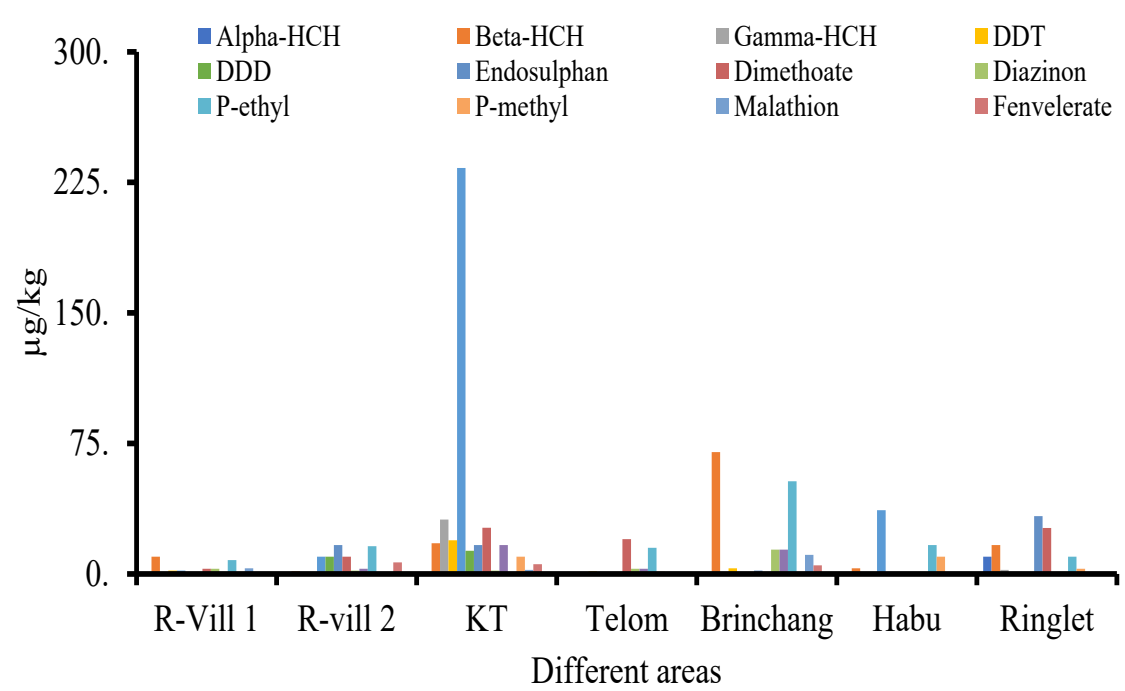

FIGURE 2. Concentration levels of pesticides in the vegetable sample from seven different areas during dry season

The number of sheltered farms increases down the valley, thus further enhancing the trapping of pesticides depending on the volatility of the compound (Ma et al. 2006). During the dry season, the trend for highest concentration for $\mathrm{HCHs}$ and endosulphan were found at Brinchang, $\mathrm{Habu}$, and Ringlet region $(\alpha-\mathrm{HCH} 10$, $\beta$-HCH 70 and $\mathrm{\gamma}$-HCH $31.3 \mu \mathrm{g} \mathrm{kg}^{-1}$ ) indicating that the rainfall effect cannot be completely neglected during dry season as wet and dry seasons are not completely separated from each other (Saadati et al. 2012). DDT concentration was highest at Kuala Terla (DDT 19.3, DDD 13.3, and DDE $233.3 \mu \mathrm{g} \mathrm{kg}^{-1}$, respectively). In the case of OPPs, the total concentration of pesticides in the wet season was more as compared to the dry season (Figures $1 \& 2$ ). 
During the wet season, the OPPs distribution seems to be dispersed, unlike OCPs, as few of OPPs were found more at the upper part of the valley and others down the valley. Dimethoate, which is found in the highest concentration among OPPs, is highly soluble in water. It seems that due to its continuous wash off by rain, farmers were applying this continuously due to pest infestation. The highest concentration for dimethoate, chlorpyriphos, and malathion was found at Raja village and Brinchang (125, 80, and $17 \mu \mathrm{g} \mathrm{kg}^{-1}$, respectively) while parathion ethyl and parathion methyl concentration were found to be highest in Habu region (133.3 and $66.6 \mu \mathrm{g} \mathrm{kg}^{-1}$ ). In the case of diazinon, the highest concentration was found at Ringlet $\left(36.3 \mu \mathrm{g} \mathrm{kg}^{-1}\right)$. This indicates that the concentration of OPPs changes as the rainfall pattern changes. The highest concentration at Raja village and Brinchang indicated that during the wet season farmers were applying pesticides more frequently as reported previously (Mazlan \& Mumford 2005). This indicated the highest percentage of spray interval 1-3 day spraying during the wet season in this zone. The presence of a high concentration of diazinon down the valley indicated that loose soil texture and high rainfall caused leaching down the valley (Tan \& Beh 2015). This also indicated that OPPs were continuously used in a conventional farming system in the study area. In the dry season, higher pesticide concentration of dimethoate, chlorpyriphos, and parathion ethyl $\left(26.6,16.6\right.$, and $\left.56.6 \mu \mathrm{g} \mathrm{kg}^{-1}\right)$ were found at Kuala Terla, diazinon and malathion (14 and 11 $\left.\mu \mathrm{g} \mathrm{kg}^{-1}\right)$ at Brinchang, and parathion methyl at Habu (10 $\left.\mu \mathrm{g} \mathrm{kg}^{-1}\right)$.

PYRs concentration was comparatively less than OCPs and OPPs. In the dry season, permethrin was not detected in all stations as shown in Figure 3. In the wet season, its concentration was higher at Ringlet region $\left(10.1 \mu \mathrm{g} \mathrm{kg}^{-1}\right)$ while for fenvelerate in wet season highest concentration was found at Ringlet region and in dry season highest at $\mathrm{Habu}\left(23.6 \mu \mathrm{g} \mathrm{kg}^{-1}\right)$ as depicted in Figure 4. During the wet season, it was found that the detection frequency was higher for pesticides, indicating its frequent use in the area for reducing pests. The frequency of negligible detection was highest in permethrin (68.7\%) followed by endosulphan $(26.3 \%)$ and $\mathrm{\gamma}-\mathrm{HCH}(50 \%)$. The detection frequency of pesticides for less than $5 \mu \mathrm{g}$ $\mathrm{kg}^{-1}$ was highest for $\beta-\mathrm{HCH}(36.8 \%)$, followed by fenvelerate $(46.5 \%)$ and dimethoate $(31.5 \%)$. Between $5<-<100 \mu \mathrm{g} \mathrm{kg}^{-1}$, the highest detection frequency was found for malathion $(58.8 \%)$, followed by endosulphan

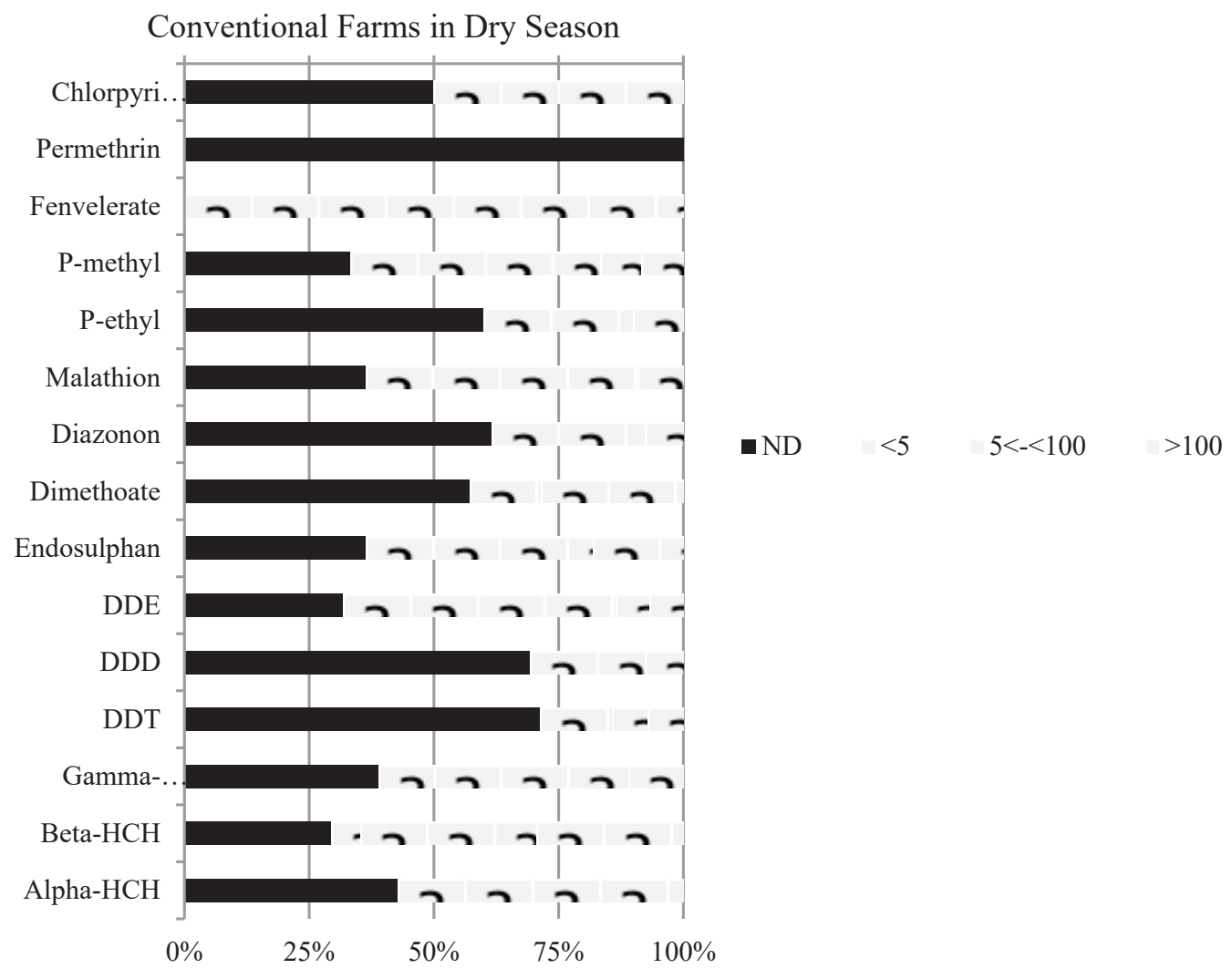

FIGURE 3. Distribution of total vegetable samples for each pesticide according to percentages of samples in which the pesticides were not detected (ND) (concentration $<5,5<-<100 \mu \mathrm{g} \mathrm{kg}^{-1},>100 \mu \mathrm{g} \mathrm{kg}^{-1}$ ) in dry seasons 


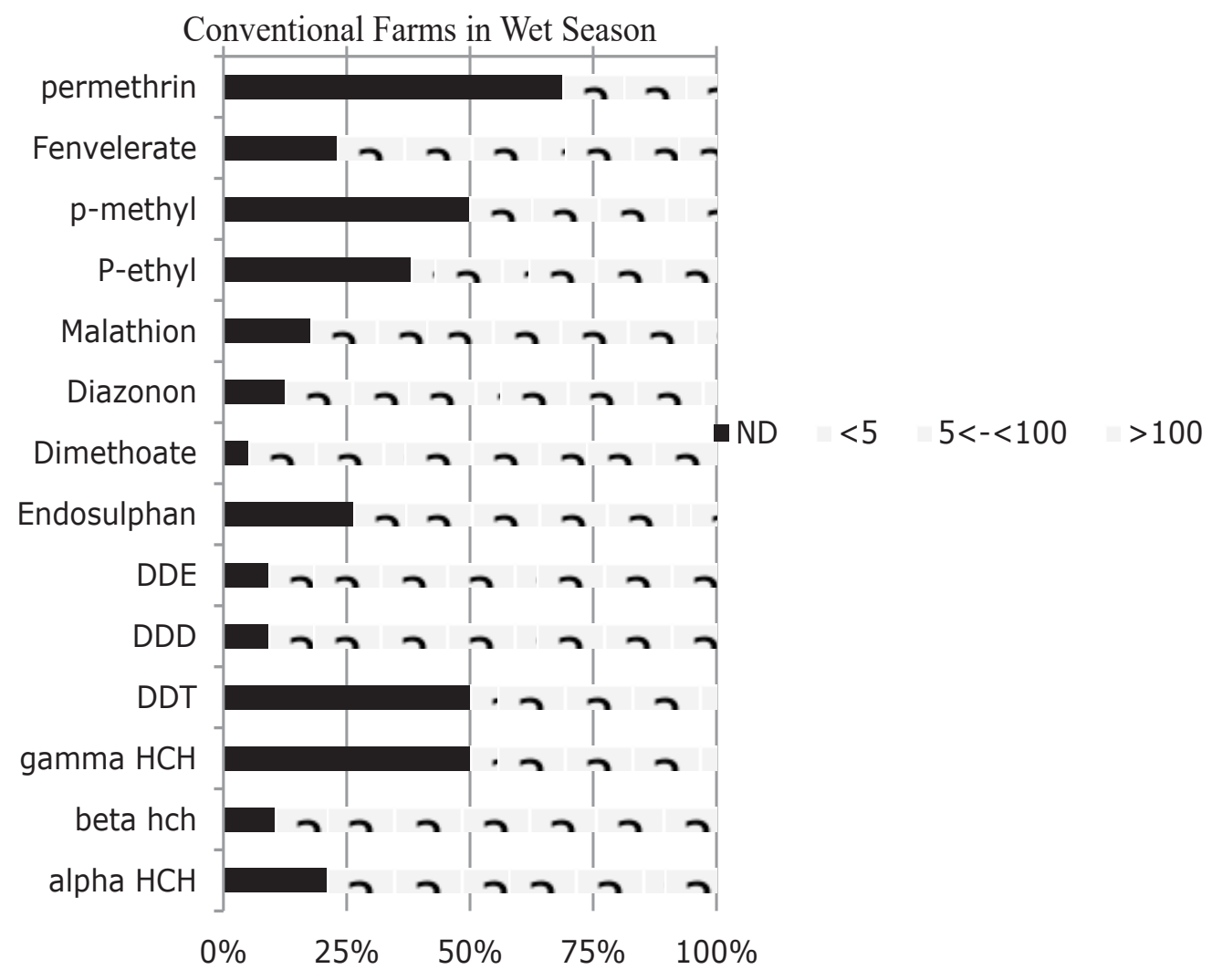

FIGURE 4. Distribution of total vegetable samples for each pesticide according to percentages of samples in which the pesticides were not detected (ND) (concentration $<5,5<-<100 \mu \mathrm{g} \mathrm{kg}^{-1},>100 \mu \mathrm{g} \mathrm{kg}^{-1}$ ) in wet season

$(57.8 \%)$ and DDE $(45.4 \%)$. For a concentration higher than $>100 \mu \mathrm{g} \mathrm{kg}^{-1}$, diazinon accounted most (43.7\%) followed by DDD (36.8\%) and DDE (36.3) indicating both aerobic and anaerobic degradation of DDT. In the wet season, the detection frequency was comparatively more for $100 \mu \mathrm{g} \mathrm{kg}^{-1}$ samples as compared to the dry season. The detection frequency was highest for most of the pesticides within a range of $5<-<100 \mu \mathrm{g} \mathrm{kg}^{-1}$ (Figure 3 ). During the dry season, most of the pesticides were not detected indicating its less useful. Permethrin was not detected throughout the season followed by DDD, dimethoate, and diazinon $(69 \%, 61.1 \%$, and $57.1 \%$ ) (Figure $3)$. Detection frequency for $<5 \mu \mathrm{g} \mathrm{kg}^{-1}$ was found highest for $\alpha-\mathrm{HCH}(57.1 \%)$ followed by DDE (57.1) and fenvelerate $(100 \%)$. The result obtained for the detection frequency of pesticides within the range of $5<-<100$ $\mu \mathrm{g} \mathrm{kg}{ }^{-1}$ was highest for $\beta$-HCH $(38.8 \%)$ followed by $\gamma$-HCH $(35.3 \%)$, dimethoate $(28.5 \%)$ and chlorpyriphos $(25 \%)$. Only a few pesticides had concentrations higher than $100 \mu \mathrm{g} \mathrm{kg}^{-1}$ of which $\gamma-\mathrm{HCH}(29.4 \%)$ was dominant followed by $\beta-\mathrm{HCH}$ (11\%), parathion methyl (8.3\%). This indicates that very few samples had concentration more than $100 \mu \mathrm{g} \mathrm{kg}^{-1}$ except $\beta-\mathrm{HCH}$, which indicates its higher presence due to thermodynamic stability as both $\gamma-\mathrm{HCH}$ and $\alpha-\mathrm{HCH}$ converts into $\beta-\mathrm{HCH}$. In the dry season, the detection frequency was more for pesticide concentration that is less than $<5 \mu \mathrm{g} \mathrm{kg}^{-1}$ (Figure 3).

After performing the PCA analysis, Eigenvalue indicated that $98.2 \%$ of data variance could be explained by five main components. Principal component 1 (PC1) accounted for $38.1 \%$ of data variability and is related to DDTs, chlorpyriphos, and fenvelerate indicates that they are coming from the same sources. PC2 contains $21.7 \%$ of data variability and its main contributors were $\mathrm{\gamma}-\mathrm{HCH}$, endosulphan, and parathion ethyl. PC3 (17.9\% variance) highlighted the combination of $\alpha-\mathrm{HCH}$ and parathion ethyl. PC4 (11.8\% variance) includes $\alpha-\mathrm{HCH}$, $\beta-\mathrm{HCH}$, and permethrin and PC5 (8.6\% variance) $\alpha-\mathrm{HCH}$, parathion methyl, and malathion as presented in Table 1. 
TABLE 1. Principal loading of main factors (in bold) of principal component analysis

\begin{tabular}{|c|c|c|c|c|c|}
\hline Variable & $\mathrm{PC} 1$ & PC2 & PC3 & $\mathrm{PC} 4$ & PC5 \\
\hline$\alpha-\mathrm{HCH}$ & -0.02 & -0.11 & -0.44 & -0.38 & 0.34 \\
\hline$\beta-\mathrm{HCH}$ & -0.25 & 0.32 & -0.10 & -0.37 & 0.08 \\
\hline $\mathrm{\gamma}-\mathrm{HCH}$ & -0.25 & 0.42 & -0.05 & 0.02 & -0.13 \\
\hline DDE & 0.36 & 0.22 & -0.04 & 0.01 & 0.02 \\
\hline DDD & 0.33 & 0.25 & -0.15 & 0.18 & 0.11 \\
\hline DDT & 0.35 & 0.14 & 0.02 & -0.34 & 0.04 \\
\hline Endosulphan & -0.24 & 0.43 & -0.11 & 0.01 & 0.05 \\
\hline Dimethoate & 0.25 & 0.16 & 0.38 & -0.10 & 0.09 \\
\hline Diazinon & -0.11 & 0.51 & 0.12 & 0.03 & -0.11 \\
\hline$P$-methyl & 0.22 & -0.10 & -0.37 & -0.09 & 0.43 \\
\hline$P$ - ethyl & 0.10 & 0.16 & -0.44 & -0.02 & 0.36 \\
\hline Chlorpyriphos & 0.33 & 0.20 & -0.15 & 0.26 & -0.17 \\
\hline Malathion & 0.19 & 0.005 & 0.27 & 0.32 & 0.5 \\
\hline Fenvelerate & 0.34 & 0.06 & 0.14 & -0.22 & -0.35 \\
\hline Permethrin & 0.1 & -0.03 & 0.35 & -0.55 & 0.129 \\
\hline
\end{tabular}

The biplot indicated that vegetables such as cabbage, spinach, cauliflower, and celery lie close together and contaminated by the majority of pesticides as compared to broccoli, lettuce, and mustard as shown in Figure 5. These observations again signify the importance of pesticide application on crop type.

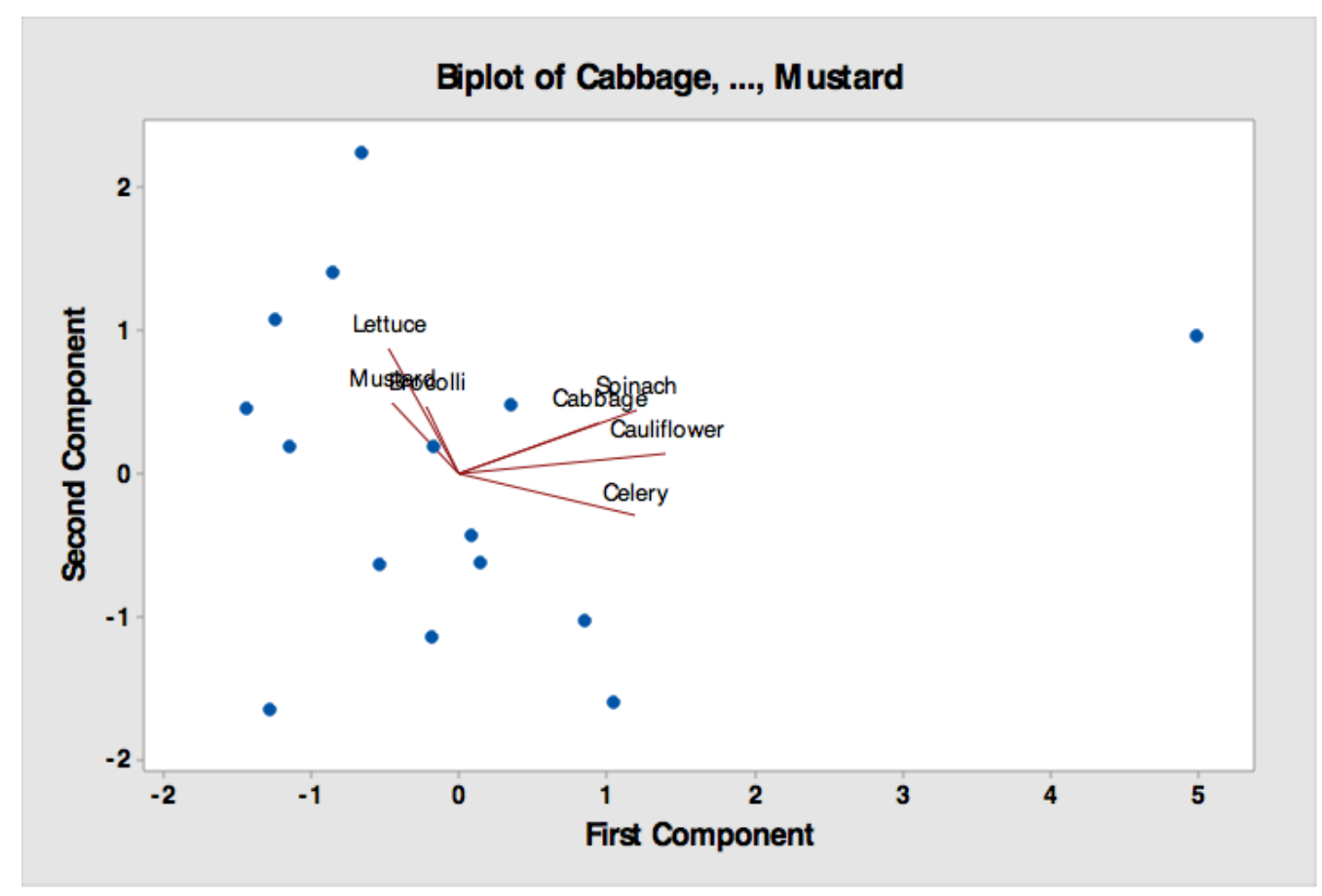

FIGURE 5. Biplot indicating the concentration of pesticides in vegetable samples 


\section{CONCLUSION}

We used a multi-residue method for pesticide analysis in different vegetable samples. Pesticides concentration was highest in the wet season than dry season indicating frequent use of pesticides due to continuous wash off by rain. The topography of the area along with the air circulation plays an important role in the distribution of pesticides in the region. OPPs concentration was more than OCPs and PYRs indicating its frequent use in the farming system. Among OCPs very few samples had concentration more than $100 \mu \mathrm{g} \mathrm{kg}^{-1}$ except $\beta-\mathrm{HCH}$, which indicates its higher presence due to it is thermodynamic stability as both $\alpha-\mathrm{HCH}$ and $\mathrm{\gamma}-\mathrm{HCH}$ converts into $\beta-\mathrm{HCH}$. OCPs concentration increases down the valley as the number of sheltered farms increases down the valley, thus further enhancing the trapping of pesticides depending on the volatility of the compound. During the wet season, the OPPs distribution seems to be dispersed, unlike OCPs, as few of OPPs were found more at the upper part of the valley and others down the valley. Dimethoate, which is found in the highest concentration among OPPs, is highly soluble in water. It seems that due to its continuous wash off by rain, farmers are applying this continuously due to pest infestation. PYRs concentration was less than both OPPs and OCPs in the dry season its detection was almost negligible. PCA analysis indicates that mixtures of pesticides are used and the application of pesticides depends upon the crop type.

\section{ACKNOWLEDGEMENTS}

Authors wish to thank the Government of Malaysia for grant FRGS/2/2013/STO1/UKM/01/2 and Universiti Kebangsaan Malaysia for DPP-2015-053. We thank Universiti Kebangsaan Malaysia for providing the facilities. Nusrat Munawar would like to thank Sardar Bahadur Khan Women University (SBKWU) for approval of the study leave and the Pakistan Government for awarding the scholarship.

\section{REFERENCES}

Abdullah, M.P., Abdul Aziz, Y.F., Othman, M.R. \& Abdul Khalik, W.M.A. 2015. Organochlorine pesticide residue level in surface water of Cameron Highlands, Malaysia. Iranica Journal of Energy and Environment 6(2): 141-146.

Bhanti, M. \& Taneja, A. 2007. Contamination of vegetables of different seasons with organophosphorous pesticides and related health risk assessment in northern India. Chemosphere 69(1): 63-68.

Farina, Y., Munawar, N., Abdullah, M.P., Yaqoob, M. \& Nabi, A. 2018. Fate, distribution, and bioconcentration of pesticides impact on the organic farms of Cameron Highlands, Malaysia. Environmental Monitoring and Assessment 190(7): 386.

Farina, Y., Abdullah, M.P., Bibi, N. \& Khalik, W.M.A. 2017. Determination of pesticide residues in leafy vegetables at parts per billion levels by a chemometric study using GCECD in Cameron Highlands, Malaysia. Food Chemistry 224: 55-61.

Gao, F., Jia, J. \& Wang, X. 2008. Occurrence and ordination of dichlorodiphenyltrichloroethane and hexachlorocyclohexane in agricultural soils from Guangzhou, China. Archives of Environmental Contamination and Toxicology 54(2): 155-166.

Hao, H., Sun, B. \& Zhao, Z. 2008. Effect of land use change from paddy to vegetable field on the residues of organochlorine pesticides in soils. Environmental Pollution 156(3): 1046-1052.

Ismail, B.S. \& Haron, S.H. 2017, Heavy metal and insecticide distribution and accumulation at the Bertam Agricultural Watershed in Cameron Highlands, Pahang, Malaysia. Water Conservation and Management 1(1): 4-6.

Ligani, S. \& Hussen, A. 2014. Determination of organochlorine pesticide residue levels in chewable parts of the Khat (Catha edulis) plant. Bulletin of Environmental Contamination and Toxicology 93(5): 591-595.

Ma, C.K., Ngan, C.K. \& Lim, K.P. 2006. The decline of pesticide residues in the air of three rain shelter farms at Cameron Highlands. Journal of Tropical Agriculture and Food Science 34(1): 173-180.

Mazlan, N. \& Mumford, J. 2005. Insecticide use in cabbage pest management in the Cameron Highlands, Malaysia. Crop Protection 24(1): 31-39.

Ngan, C.K., Cheah, U.B., Abdullah, W.W., Lim, K.P. \& Ismail, B.S. 2005. Fate of chlorothalonil, chlorpyrifos and profenofos in a vegetable farm in Cameron Highlands, Malaysia. Water, Air, \& Soil Pollution: Focus 5(1-2): 125-136.

Park, D.W., Kim, K.G., Choi, E.A., Kang, G.R., Kim, T.S., Yang, Y.S., Moon, S.J., Ha, D.R. Kim, E.S. \& Cho, B.S. 2016. Pesticide residues in leafy vegetables, stalk and stem vegetables from South Korea: A long-term study on safety and health risk assessment. Food Additives \& Contaminants: Part A 33(1): 105-118.

Saadati, N., Abdullah, M.P., Zakaria, Z., Rezayi, M. \& Hosseinizare, N. 2012. Distribution and fate of $\mathrm{HCH}$ isomers and DDT metabolites in a tropical environmentcase study Cameron Highlands-Malaysia. Chemistry Central Journal 6(1): 130.

Sinha, S.N., Rao, M.V.V. \& Vasudev, K. 2012. Distribution of pesticides in different commonly used vegetables from Hyderabad, India. Food Research International 45(1): 161-169.

Sulaiman, N., Fong, T.L., Samat, H.A., Sahid, I., Othman, R. \& Abdullah, M. 2007. Concentration of insecticides cypermethrin isomer in total suspended particulate in air of Cameron Highlands, Pahang, Malaysia. Sains Malaysiana 36(2): 97-103. 
Tan, K.W. \& Beh, W.C. 2015. Water quality monitoring using biological indicators in Cameron Highlands Malaysia. Journal of Sustainable Development 8(3): 28-42.

World Health Organization. 2003. Diet, Nutrition, and the Prevention of Chronic Diseases: Report of a Joint WHO/FAO Expert Consultation (Vol. 916). World Health Organization.

Nusrat Munawar

Department of Chemistry Faculty of Science

Sardar Bahadur Khan Women University, Quetta

Pakistan

Yang Farina*

Centre for Water Research and Analysis (ALIR)

Faculty of Science and Technology

Universiti Kebangsaan Malaysia

43600 UKM Bangi, Selangor Darul Ehsan

Malaysia
Yang Farina*

Department of Chemical Sciences

Faculty of Science and Technology

Universiti Kebangsaan Malaysia

43600 UKM Bangi, Selangor Darul Ehsan

Malaysia

Mohammad Yaqoob \& Abdul Nabi

Department of Chemistry

University of Balochistan

87300 Quetta

Pakistan

Syed Munawar Shah

Faculty of Management Sciences

BUITEMS University

City Campus, Quetta

Pakistan

*Corresponding author; email: farina@ukm.edu.my

Received: 22 October 2020

Accepted: 21 February 2021 